<原 著 $>$

\title{
glucagon-insulin による肝不全の治療
}

\section{第 1 報 glucagon-insulin 療法による肝性脳症の \\ 改善と血中アンモニアの変動}

\begin{tabular}{|c|c|c|c|c|}
\hline 菅 & 充生** & 細川 幸夫 & 横山 & 洋子 \\
\hline 木下 & 博 & 哲郎* & 藤嶋 & 彰 \\
\hline 田 & 英雄 & 斉藤美知子 & 白井 & 祐一** \\
\hline
\end{tabular}

要 旨 : 肝性脳症を伴 急性肝不全 2 例, 慢性肝不全 6 例に glucagon-insulin (以下 G-I) 療法 を行い，本療法の有効性を検討した。その結果 G-I 療法で救命できたものは，急性肝不全 $2 / 2$ 例, 慢性肝不全 $2 / 6$ 例で, 半数で救命効果があった，一時的覚醒例を含めて，経過中意識 レベル の改善を認めたものは7/8例であり，覚醒までの治療日数は平均 4 日であった. 肝性脳症改善前後 の血中アンモニア值を比較すると，有効例では治療前 $177 \pm 86 \mu \mathrm{g} / \mathrm{d} l$ と上昇していたアンモニア が，覚醒後は $75 \pm 47 \mu \mathrm{g} / \mathrm{d} l$ と減少したが，無効例では減少は認められなかった.ささらに G-I 点滴 静注前後 3 時間内に, アンモニアの著明な減少を認めた. 肝機能検査では急性肝不全 2 例はとも に GOT, GPT の改善があったが，慢性肝不全では明らかな傾向は認められなかった，以上より G-I 療法は従来の治療法に少らない極めて有効な治療法であり，本療法の作用機序について，文 献的考察を加えた.

索引用語： glucagon-insulin 療法 肝不全 肝性脳症 アンモニア

\section{緒 言}

重症肝疾患のさいに発現する肝性脳症は，旰機能不全 により若起される脳症状であり，極めて多彩な代謝異常 の結果生しるるのとされている.この代謝異常は，肝実 質の機能脱落により生じるもの(Leberinsuffizienz durch Leberzerfall) と，副血行路により門脈血が直接大循環 に入る結果生じるるの (Leberinsuffizienz durch Leberausfall）の 2 つ分類され，前者は劇症肝炎炕よる急性 䀒不全, 後者は肝硬変症の非代償期炕生じる慢性肝不全 が代表的なるのである.

これらの肝不全によって生じる肝性脳症は，臨床的に は両者を合併するものが多く，また成立機序についても まだ定説がないため，種及の治療法の導入によってもそ の死亡率は今日なお高率である。

* 市立室蘭総合病院内科

** 札幌医科大学第 1 内科（主任：谷内 昭教授） <受付日55年 5 月19日 $>$
しかし治療法の根本は，体内で生成されたアンモニフ などの有毒物質を除去し，肝において生成される物質を 充分に補給し，さらに機能不全に招らいった肝細胞の再 生を早期に計ることにある.

近年 Bucher $5^{1)}$ の glucagon-insulin の共役的作用に 上る肝再生促進効果の報告以来, 同療法の肝不全に対す る有効性が実験的にも臨床的にも実証されつつある. 著 者らは急性肝不全 2 例，慢性肝不全 6 例飞 G-I 療法を 行い, 肝性脳症の改善効果叔よび救命効果を確認し得た ので報告する.

\section{研究方法}

対象は市立室蘭総合病院内科に入院した肝性脳症を伴 5 劇症肝炎 2 例, 肝硬変症 6 例で, Trey ら 症度の分類では， II 度 3 例， III度 3 例，IV度 2 例であ る.

G-I 療法は $5 \%$ ブドゥ糖 $500 \mathrm{~m} l$ regular insulin (Novo 社) 12単位, glucagon (Novo 社) $1 \mathrm{mg}$ を混合 
し，約 3 時間で点滴静注した。この点滴静注を通常は 1

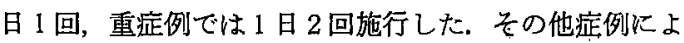
$\eta$ prednisolone, $l$-DOPA の点滴静注特よび lactulose 注 腸を行った.

G-I 療法の効果判定として, 肝性腷症 の重症度 の 改

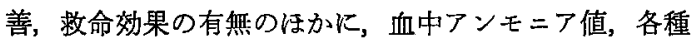
肝機能検查，血清カリウム，尿素窒素などを指漂とし た.

\section{症例}

症例の要約は Table 1 と示した.

症例 1. M.T. 17歳, 男性.

黄疾を主訴に来院，GOT 221U，GPT 828U，ALP $21.6 \mathrm{KA}$, 総ビリルビン $12.6 \mathrm{mg} / \mathrm{d} l$ のため即日入院した。 第 2 病日より意識障害と羽ばたき振戦を認め，prednisolone, $l$-DOPA の点滴静注怙よび lactulose 注腸を行っ たが，第 3 病日にアンモニアが $101 \mu \mathrm{g} / \mathrm{d} l$ と上昇， III 度 の肝性媨症となったため，劇症肝炎の診断で G-I 療法 を施行した。第 7 病日には覚醒. AFP は $782 \mathrm{ng} / \mathrm{m} l$ 之高 値を示した。第125病日に行った肝生検 では肝硬変症で あった．第217病日に退院した。

症例 2. F.Y. 66 歳, 男性.

脳卒中後遗症で某医に入院していたが，感冒様症状と ともに突然昏睡となる。 GOT 2,920U，GPT 4,160U， LDH $9,863 \mathrm{U}$ で古り，劇应肝炎（肝性脳症IV度）の診 断で当科に転入院した．血中アンモ二フは $104 \mu \mathrm{g} / \mathrm{d} l$ ，第 1 病日上り G-I 療法 1 日 2 回施行し，第 4 病日には覚醒 した．現在入院加療中であるが，肝機能検查では GOT 62 U のみが異常值である。

症例 3. K.Y. 42歳，女性

肝硬变症之糖尿病で外来治療中であったが，突然昏迷 状熊となり入院 した．GOT 57U, GPT 29U，血中フン
モニフは $309 \mu \mathrm{g} / \mathrm{d} l$ と高値を示していた．肝硬变症によ る肝性腷淀（III度）之診断，第 1 病日より G-I 療法の ほか lactulose 注腸を行い，第 4 病日にはアンモ二アは $165 \mu \mathrm{g} / \mathrm{d} l$ と減少し，意識は正常化した．現在入院加療 中である。

症例 4. T.M. 54歳, 男性.

下肢浮腫と腹部膨満感を主訴に来院，精查のため入院 した. 入院時肝瘇と腹水を認め，GOT 25U，GPT 12U であった。第48病日より傾眠状態となり，羽ばたき振戦 特よび脳波で 3 相波を認めた。 アンモニアは $141 \mu \mathrm{g} / \mathrm{d} l$ と 增加, 肝硬変症に上る肝性脳症（而度）々診断し，同日 より G-I 療法を開始した＼cjkstart第49病日にはアンモニアの 減少とともに意識清明となり，第154病日に退院した。

症例 5. T.I. 52藏，男性.

5 年前より慢性肝资で治潦中であったが，傾眠状態と なったため入院した，肝機能検查で GOT 140U, GPT $84 \mathrm{U}$, 総ビリルビン $1.2 \mathrm{mg} / \mathrm{d} l$, アンモ二ア $138 \mu \mathrm{g} / \mathrm{d} l$ であ り, 肝硬变症に上る肝性脳症 (III度) 之診断，第 1 病日 より G-I 療法を施行した。第3 病日には意識清明とな ク, アンモニアは $62 \mu \mathrm{g} / \mathrm{d} l$ に隇少した。 G-I 療法は 8 日 間行った。第45病日飞昍血があり，第46病日に死亡し た.

症例 6. S.O. 73歳，女性.

吐血で緊急入院した．胃内視鏡検查で胃角部に潰湯が あるため，輸血 3 単位を行ったが，第 5 病日より昏睡状 態となった。肝機能検查で GOT $34 \mathrm{U}$, GPT $34 \mathrm{U}, \mathrm{LDH}$ $470 \mathrm{U}$, 血清総タンパク $6.7 \mathrm{~g} / \mathrm{d} l, \gamma$-グロブリン $36.2 \%$ ，フ ンモニア $290 \mu \mathrm{g} / \mathrm{d} l$ であり，肝硬変症による肝性脳症 (IV 度) 々診断 L，G-I 療法と l-DOPA の点滴静注を行い, 第 8 病日にアンモニアは $110 \mu \mathrm{g} / \mathrm{d} l$ と減少し，意識清明 そなった．その後経過は良好であったが，第68病日より

Table 1. Effect of glucagon-insulin therapy in patients with hepatic encephalopathy

\begin{tabular}{|c|c|c|c|c|c|c|c|c|}
\hline case & sex & age & diagnosis & HBsAg & HBsAb & therapy* & grade of coma & prognosis \\
\hline 1. M. T. & $\mathbf{M}$ & 17 & fulminant hepatitis & $(+)$ & $(+)$ & $P, D, L$ & $3 \longrightarrow 0$ & alive \\
\hline 2. F. $Y$. & $\mathbf{M}$ & 66 & fulminant hepatitis & $(-)$ & $(+)$ & - & $4 \longrightarrow 0$ & alive \\
\hline 3. K. Y. & F & 42 & liver cirrhosis & $(-)$ & $(+)$ & $\mathrm{L}$ & $3 \longrightarrow 0$ & alive \\
\hline 4. T. M. & $\mathbf{M}$ & 54 & liver cirrhosis & $(+)$ & $(-)$ & $D, \quad$ L & $3 \longrightarrow 0$ & alive \\
\hline 5. T. I. & $\mathbf{M}$ & 52 & liver cirrhosis & $(+)$ & $(-)$ & L & $2 \longrightarrow 0$ & died \\
\hline 6. S. O. & $F$ & 73 & liver cirrhosis & $(-)$ & $(+)$ & D & $4 \rightarrow 0 \rightarrow 4$ & died \\
\hline 7. M. A. & $\mathbf{M}$ & 48 & liver cirrhosis & & & P, L & $2 \longrightarrow 0$ & died \\
\hline 8. J. O. & $\mathbf{M}$ & 53 & liver cirrhosis & $(-)$ & $(t)$ & - & $2 \longrightarrow 4$ & died \\
\hline
\end{tabular}

* $\mathrm{P}$; prednisolone $\mathrm{D}$; $l$-DOPA $\mathrm{L}$; lactulose 
再度昏睡となり，第71病日に死亡した.

症例 7. M.A. 48墄, 男性.

昭和53年より悪性リンパ尰で治療中であったが，昭和 54年10月より感冒様症状とともに黄疸を認め入院した。 入院時総ビリルビン $11.2 \mathrm{mg} / \mathrm{d} l$, GOT $223 \mathrm{U}$, GPT 178 $\mathrm{U}, \mathrm{LDH} 510 \mathrm{U}$, アンモニ $119 \mu \mathrm{g} / \mathrm{d} l$ であった. prednisolone の点滴静注と lactulose 投与を行ったが, 第15病 日より傾眠状態となり，羽ばたき振戦出現，アンモニア は $155 \mu \mathrm{g} / \mathrm{d} l$ と増加したため, 肝性脳症 (II 度) と診断 し同日より G-I 療法 1 日 2 回施行 した。第19病日に意 識清明となったが，第23病日より下血，吐血があり，第 25病日に死しした．剖検では甲型肝硬変症であった。

症例 8. J.O. 53藏, 男性.

黄㾞を主訴に来院し入院した。入院時意識障害なく, 総ビリルビン $14.9 \mathrm{mg} / \mathrm{d} l$, GOT $147 \mathrm{U}$, GPT $49 \mathrm{U}$, 総夕 ンパク $7.4 \mathrm{~g} / \mathrm{dl}, \gamma$-グロプリン $35.8 \%, \quad フ ン モ=フ 39 \mu \mathrm{g} /$ $\mathrm{d} l$ であった，第 5 病日より傾胝状態となり羽ばたき振 戰を認めた. 肝硬变症に上る肝性脳症 (II 度) と診断 し，第 7 病日より G-I 療法を開始したが，第11病日に はアンモ 度）を認め，第13病日に意識の覚醒効果なく死亡した。

\section{成 績}

\section{1. 意識レベルの改善効果}

经過中一時的覚醒例を含めて, 意識レベルの改善がみ られたものは，8例中 7 例であった．肝性脳症の重症度 別では，II 度2/3例， III度3/3例，IV度2/2例に効果があ り，G-I 療法開始より覚醒までの期間は平均 4 日であっ た.

\section{2. 救命効果}

劇症肝资 2 例はいずれる G-I 療法で救命している. 肝硬変症による肝不全では 6 例中 2 例に救命効果があっ た. 死亡例は出血 2 例, 肝性脳症の増悪 2 例で, 重症度 による救命効果は，II 度0/3例，III度3/3例，IV度 $1 / 2$ 例で あった。平均50\%に救命効果が認められた。

\section{3. 血中アンモニアの变動}

G-I 療法前と覚醒直後のアンモニア值を Table 2 に示 した. 治療前全例がアンモニアの異常值を示し，意識の 改善効果を認めた例では，アンモニアは G-I 療法前に 平均 $177 \pm 86 \mu \mathrm{g} / \mathrm{d} l$ であったが，覚醒後は75土47 $\mu \mathrm{g} / \mathrm{d} l$ ま で減少し，その減少率は57.6\%であったしかし意識の 改善効果のない症例では，G-I 療法にすかかわらす゚アン モニアの変動はなかった.

G-I 点滴静注前後 3 時間に血中アンモニアを測定し得
Table 2. Time required for improvement of hepatic encephalopathy and changes of plasma ammonia levels by glucagon-insulin treatment

\begin{tabular}{|c|c|c|}
\hline case & $\begin{array}{l}\text { time required } \\
\text { for awakening }\end{array}$ & $\begin{array}{l}\text { levels of plasma } \\
\text { ammonia }(\mu \mathrm{g} / \mathrm{dl})\end{array}$ \\
\hline 1. M. T. & 5 days & $101 \longrightarrow 54$ \\
\hline 2. F. Y. & 4 & $104 \longrightarrow 41$ \\
\hline 3. K. $\mathrm{Y}$. & 4 & $309 \longrightarrow 165$ \\
\hline 4. T. M. & 2 & $141 \longrightarrow 29$ \\
\hline 5. T. I. & 3 & $138 \longrightarrow 62$ \\
\hline 6. S. O. & 4 & $290 \longrightarrow 110$ \\
\hline 7. M. A. & 5 & $155 \longrightarrow 63$ \\
\hline 8. J. O. & 一 & $147 \longrightarrow 158$ \\
\hline
\end{tabular}

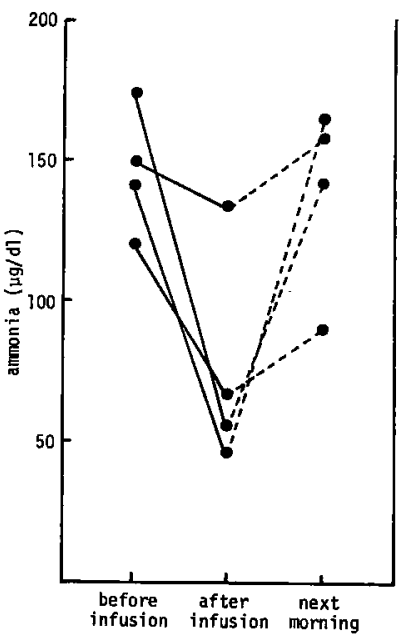

Fig. 1 Changes of plasma ammonia levels before and after glucagon-insulin infusion.

た 4 例の変動をみると (Fig. 1), 点滴前にはアンモニア

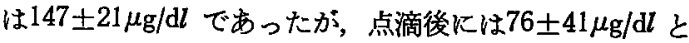
著明な減少を認め，その平均減少率は48.3\%であった。 しかし翌朝には $139 \pm 34 \mu \mathrm{g} / \mathrm{d} l$ と増加して扰り， G-I 療 法に拈けるアンモ二アの変動は，短時間のうちに出現す ることが示唆された。

\section{4. 肝機能検查の変動}

肝性脳症時と覚醒後の肝機能検查を比較すると，総ビ リルビンは劇症肝炎 2 例で上昇し，肝硬変症 5 例では 3 例に減少傾向を認めた. GOT, GPT は劇症肝资では著 明な低值となったが，肝硬変症では一定の傾向は認めら れなかった. 血中アルブミン值は 5 例で減少, 2 例で微 増があった、肝機能検査上 G-I 療法により变動をきた 
Table 3. Changes of clinical data during and after recovery from hepatic encephalopathy

\begin{tabular}{|c|c|c|c|c|c|c|c|c|c|c|c|c|}
\hline \multirow{2}{*}{$n_{\text {case }}$} & \multicolumn{2}{|c|}{ T. Bil. } & \multicolumn{2}{|c|}{ GOT } & \multicolumn{2}{|c|}{ GPT } & \multicolumn{2}{|c|}{ Albumin } & \multicolumn{2}{|c|}{ BUN } & \multicolumn{2}{|c|}{$\mathrm{K}$} \\
\hline & $(t)$ & $(-)$ & $(+)$ & $(-)$ & $(+)$ & $(-)$ & $(+)$ & $(-)$ & $(+)$ & $(-)$ & $(+)$ & $(-)$ \\
\hline 1. M. T. & 13.5 & 23.5 & 221 & 37 & 828 & 106 & 4.1 & 2.8 & 10 & 16 & 4.8 & 4.7 \\
\hline 2. F. Y. & 3.5 & 5.1 & 3650 & 48 & 5880 & 332 & 4.1 & 3.0 & 32 & 22 & 4.1 & 3.7 \\
\hline 3. K. Y. & 2.0 & 1.0 & 57 & 19 & 29 & 11 & 3.0 & 2.9 & 18 & 10 & 3.7 & 3.4 \\
\hline 4. T. M. & 1.0 & 1.0 & 25 & 29 & 12 & 18 & 4.4 & 3.4 & - & - & 3.9 & 4.4 \\
\hline 5. $\mathrm{T}, \mathrm{I}$. & 1.0 & 1.2 & 140 & 63 & 84 & 39 & 2.5 & 2.6 & 25 & - & 4.3 & 5.0 \\
\hline 6. S. O. & 3.1 & 2.7 & $34:$ & 28 & 34 & 17 & 3.3 & 2.4 & 27 & - & 3.5 & 2.5 \\
\hline 7. M. A. & 13.4 & 10.2 & 95 & 121 & 83 & 35 & 2.2 & 2.1 & 21 & 10 & 4.0 & 4.2 \\
\hline 8. J. O. & - & - & 147 & 215 & 49 & 58 & 3.2 & 3.3 & 10 & - & 5.1 & 5.4 \\
\hline
\end{tabular}

$(+)$; during hepatic encephalopathy

(-) ; after recovery from hepatic encephalopathy

したものは，劇症肝炎 2 例に拈ける GOT, GPT の改善 が特徴的であった (Table 3).

\section{5. その他}

BUN については，肝性脳症出現前後に測定し得た症 例が少なく，比較はできなかった. 血中カリウムは全例 正常域にあり，一定の傾向は認められなかった。

\section{考案}

肝珄脳症を伴なう急性肝不全袄よび慢性肝不全 8 例に G-I 療法を行い，その効果について検討を加えた。 それ らを要約すると, 意識レベルの改善効果は7/8例, 救命効 果は4/8例に認められ，意識覚醒 までの 平均治療日数は 4 日であった．また覚醒例の全例に特いて，G-I 療法に より著明なアンモニアの減少が認められた。

肝性脳症の発生機序については，現在まで種々の説が 唱亮られているが定説はなく，その中でアンモニア，フ ミノ酸やアミン類，低級脂肪酸などの関与について比較 的解明されつつある。

アンモニアは肝性脳症の大部分に上昇が認められ，脳 症改善とともに減少することより，唯一の原因ではない にしてむ，最も重要な因子とされている。重症肝疾患時 の高アンモニア血症の発生機序は，肝ミトコントリアの ATP 産生能が低下し：ミトュンドリアでのアンモニア 固定段階で ATP 供給不足による二次的な機能低下によ るものと考它られている゙．

フンモニアの毒性については, neurotransmitter inhibitor の GABA を増加させるという推論"などがあるが, 意識障害の程度と血中アンモニア濃度との間に相関がそ しいこどや，訮硬変症患者にアンモニウム塩を投与し
ても，臨床的に変化のない症例もあり", すべての神経 症状を説明できない.

脂肪酸については，肝性脳症患者の血浆低刺脂肪酸が 有意に増加して未り ，また血中脂肪酸の上昇はトリプ トファンの脳内とり込みに 重要な役割があるといら報 告 ${ }^{8,9)}$ むるが，不明な点が多い。

しかし最近アミノ酸の代謝に関する研究が進み，この 面上り本症の発生機序の解明が行われている. 䀒性脳症 ではフェニールアラニン, チロシン,トリプトファンな どの芳香族アミノ酸 (AAA) が増加し，ロイシン，イソ ロイシン，ハシンなど分枝アミノ酸 (BCAA) の娍少が あり，BCAA/AAA のモル比の低下が特徴とされて括り 10), この現象は肝不全による高インスリン血症のための 骨格筋に扣ける分枝アミノ酸の異化六進の結果であり， 脳内への AAA の取り込みとりわけトリプトファンの脳 内濃度が上昇し，トリプトファンの分解六進のためセロ トニンの産生増をきたし，肝性脳症が成立すると考学ら れている ${ }^{11)}$.川出ら ${ }^{12)}$ は肝性慆症患者の髄液にトリプト ファンの増加を，Knell ら 証明している.

G-I 療法は Bucher $ら^{1)}$ が, ラット閏脈域の内臟摘出 した肝の DNA 合成を指標とした肝再生実験で，glucagon，insulin 和よび両者を投与し，両者を投与した群に 颃いて著明な DNA 合成が認められたことより注目され たものである。本邦では沖田ら ${ }^{14)}$ が，D-galactosamine 腹然内投与によりラットに劇症肝炎様病変を作製し。 G-I 投与により肝再生促進効果および肝細胞壊死の進展 阻止好果を実験的飞確認し，さらに肝不全患者に G-I 
療法を行い，極めて有効であると報告している ${ }^{15)}$.

しかし臨床的には，G-I 療法により肝性脳淀改善効果 が平均 4 日と早期に認められること，G-I 点滴前後 3 時 間のらちに著明なアンモニアの減少を認めたことを，肝 再生促進作用のみで説明することは困難であり，本療法 による所不全で落起された代謝異常の改善作用が，第一 義的と考光るのが妥当であろう. 本研究では血中アンモ ニアの変動を指標としたが， G-I 療法有効例でアンモニ アの減少があることから, 本療法は肝不全により乱れた 窒素平衡を改善する作用を有すると考えられる.

アンモニア代謝に関する glucagon, insulin の作用は ほとんど解明されていないが，肝ミトコンドリアでの ATP 産生能か゚ insulin により元進すること ${ }^{16)}$ ，また zinc glucagon にはラット肝尿素サイクルの5つの酵素の誘 導作用のあること苚などより，G-I 療法による旰のフン モニア代謝回転促進が推測されるが，逆に glucagon $に$ よりアンモニアの上昇がみられたとの報告 ${ }^{18)} あ り$, 推 測の域を出ない.

また蛋白代謝に対する影響は，glucagon は蛋白分解 促進に働き ${ }^{199}$ ， insulin はアミノ酸の細胞膜透過性を促 進させるこど20)などより，BCAA/AAA のモル比改善作 用も考学られるが，これらについては今後の研究を待た なければならない。

このよ5に G-I 療法はその作用機序には不明な点が 多いにしても，臨床的には肝性脳症に対して早期の覚 醒作用および救命効果があり，さらに従来の交換輸血， 旰補助装置に比べて非常に簡便であることより，極めて 効果的な治療法と思われる。

本研究では G-I 療法に glucagon Img, insulin 12単 位を使用したが，病態によるそれぞれの必要投与量，投 与順序あるいは投与期間については，G-I の作用機序の 解明ととるに今後さらに検討の必要がある.

現在各症例のアミノ酸分析を行って拈り，第 2 報と乙 て報告する予定である.

\section{結語}

急性肝不全, 慢性肝不全による肝性脳症患者に G-I 療 法を行い，以下の成績を得た。

1）経過中に一時的覚醒例を含めて，意識レベルの改 善を認めたものは7/8例であり，覚醒さでの平均治撩日 数は 4 日であった。

2） G-I 療法で救命し得た症例は4/8例で，劇症肝炎 2 例はともに救命効果があった.

3） G-I 療法により意識レベルの改善を認めたもの全 例に，血中アンモニアの減少があり，また G-I 点滴静
注 3 時間内に，点滴前に比較して48.3\%のアンモニアの 減少が虫められた。

4）急性肝不全 2 例は著明な GOT, GPT の改善が認 められたが, 慢性肝不全では肝機能検查上特異な変動は なかった.

以上より, 肝不全による肝性脳症に対して G-I 療法 は極めて有効な治憭法であり，これらの作用機序は不明 であるが，肝再生作用のほかに，肝不全により惹起され た窒素平衡異常の改善作用があると推測した。

(本研究は厚生省「難治性の肝炎」調查研究班の補助 によった。)

\section{文 献}

1) Bucher, N.L.R. \& Swaffield, M.N.: Regulation of hepatic regeneration in rats by synergistic action of insulin and glucagon. Proc. Nat. Acad. Sci. USA, 72: 1157, 1975.

2) Trey, C. et al.: Treatment of hepatic coma by exchange blood transfusion. N. Engl. J. Med., 274: 473, 1966.

3) 小澤和恵 : 糖代謝研究法. 12) 肝の機能上 energy charge. 代謝, $15: 1645 ， 1978$.

4) Goetcheus, J.S. \& Webster, L.T. Jr.: $\gamma$ Aminobutyrate and hepatic coma. J. Lab. Clin. Med., 65: 257, 1965.

5) Summerskill, W.H.J. et al.: The metabolism of ammonia and $\alpha$-keto-acids in liver disease and hepatic coma. J. Clin. Invest., 36: 361, 1957.

6) Cohn, R. \& Castell, D.O.: The effect of acute hyperammoniemia on the electroencephalogram. J. Lab. Clin. Med., 68: 195, 1966.

7) 武藤泰敏, 高橋善弥太 : 肝疾患に括ける血㢡低 級脂酸の測定. 日内会誌，53:828，1964.

8) Knott, P.J. \& Curzon, G.: Free tryptophan in plasma and brain tryptophan metabolism. Nature, 239 : 452, 1972.

9) Curzon, G. et al.: The effect of fatty acids on the binding of tryptophan to plasma protein. Nature, 242: 198, 1973.

10) Soeters, P.B. \& Fischer, J.E.: Insulin, glucagon, aminoacid imbalance, and hepatic encephalopathy. Lancet, II: 880, 1976.

11) Munro, H.N. et al.: Insulin, plasma aminoacid imbalance, and hepatic coma. Lancet, I: 722 , 
1975.

12）川出靖彦，武藤泰敏 : 重症肝障害に㧍けるアミ ノ酸代謝異常とその対策. 肝葴, 20：1314, 1979.

13) Knell, A.J. et al.: Dopamine and serotonin metabolism in hepatic encephalopathy. Brit. Med. J., 1 : 549, 1974.

14）沖田 極他：肝疾患治療薬の作用に関する基礎 的研究 (2). 重症肝炎の治療を目的とした glucagon-insulin 療法の基礎的研究. 肝葴, 19 : $848,1978$.

15）沖田 極他：肝疾患治療薬の作用に関寸る基礎 的研究 (3). glucagon-insulin 療法による急性, 慢性肝不全の治療. 肝臓, $19: 854,1978$.

16) Ozawa, K. et al.: Role of insulin as a portal factor in maintaining the viability of liver.
Ann. Surg., 180: 716, 1974.

17) Snodgrass, P.J. et al.: Induction of urea cycle enzymes of rat liver by glucagon. J. Biol. Chem., 253: 2748, 1978.

18) Bodan, V. et al.: The effect of glucagon on free plasma amino acids in cirrhotics and healthy control. Acta. Haepato-gastroenterol., 25: 23, 1978.

19) Mortimore, G.E. et al.: Proteolysis in homogenates of perfused rat liver. Responses to insulin, glucagon and amino acids. Biochem. Biophys. Res. Commun, 54: 89, 1973.

20) Kletzien, R.F. et al.: Induction of amino acid transport in primary cultures of adult rat liver parenchymal cells by insulin. J. Biol. Chem., 251: 3014, 1976.

\title{
Treatment of hepatic insufficiency with glucagon-insulin
}

\section{Part I. Improvement of hepatic encephalopathy and changes of blood} ammonia levels by glucagon-insulin treatment

\author{
Mitsuo Suga**, Yukio Hosokawa, Yoko Yokoyama, Hiroshi Kinoshita, \\ Tetsuro AnzaI*, Akira Fujishima, Hideo Fujrta, \\ Michiko SAIto and Yuichi Shrrar**
}

The clinical effect of the treatment of hepatic encephalopathy with intravenous glucagon and insulin (G-I) was studied. Both of 2 cases with acute hepatic insufficiency survived, whereas the survival in chronic hepatic insufficiency was 2 out of 6 cases, so that the over-all survival rate was $50 \%$. Improvement of the conciousness state, including temporary arousal, was observed in 7 of 8 cases, and the average period required before arousal was 4 days. The improvements of the consciousness states were accompanied by decreases of blood ammonia levels within 3 hours after the start of the infusion, whereas this could not be observed in cases where the G-I treatment was ineffective. Cases with acute hepatic insufficiency showed improvements of GOT and GPT levels, while no appreciable impıovement was observed in chronic cases. It is concluded that the G-I treatment is a very effective method, at least no less effective than any of the conventional methods, of treatment for the control of hepatic insufficiency. The mechanism of action of this treatment was discussed.

* Department of Internal Medicine, Muroran City General Hospital (Muroran)

** Department of Internal Medicine(Section 1), Sapporo Medical Collage(Sapporo) (Director; Prof. Akira YAcHI) 